\title{
Carolyn L. Hsu, Creating Market Socialism: How ordinary People Are Shaping Class and Status in China
}

\section{Gilles Guiheux}

\section{OpenEdition \\ Journals}

Electronic version

URL: http://journals.openedition.org/chinaperspectives/3933

DOI: 10.4000/chinaperspectives.3933

ISSN: 1996-4617

\section{Publisher}

Centre d'étude français sur la Chine contemporaine

\section{Printed version}

Date of publication: 4 April 2008

Number of pages: 112-113

ISSN: 2070-3449

\section{Electronic reference}

Gilles Guiheux, "Carolyn L. Hsu, Creating Market Socialism: How ordinary People Are Shaping Class and Status in China », China Perspectives [Online], 2008/2 | 2008, Online since 01 April 2008, connection on 24 September 2020. URL : http://journals.openedition.org/chinaperspectives/3933 DOI : https://doi.org/10.4000/chinaperspectives.3933

This text was automatically generated on 24 September 2020 .

(c) All rights reserved 


\title{
Carolyn L. Hsu, Creating Market Socialism: How ordinary People Are Shaping Class and Status in China
}

\author{
Gilles Guiheux
}

1 The authorities and the governing elite are not the only agents to have a hand in shaping the emergent institutional and moral order in China. Although the one-party state took the initiative in dismantling socialist institutions, it does not act the part of an autonomous divinity; in all its diversity, society itself participates in building new institutions and value systems. These are the basic arguments underlying Carolyn L. Hsu's work. The outcome of her postgraduate research, it is one of a number of works that in recent years have paid attention to statements from ordinary citizens (the laobaixing) in order to grasp the makeup of contemporary Chinese society, ${ }^{1}$ and credit citizens with an active social role in which their activities are both adaptable and creative. Hsu's study focuses on the conditions that give rise to popular judgements concerning the social hierarchy. Her hypothesis is that ordinary people, through their deeds and their words, contribute to forming the rules that assign a profession a particular position in society as a whole. ${ }^{2} \mathrm{Hsu}$ takes citizens' discourses and practices as her point of departure in order to understand the movement from a socialist scale of values, which gave primary importance to political capital, to a contemporary order that accords greater value to human capital, that is to say, individual abilities.

2 These theoretical assumptions have methodological consequences. To appreciate how the laobaixing collaborate in the production of social hierarchies, the author reconstructs shared narratives in which she identifies implicit moral judgements referring to different kinds of capital (whether economic, social, political, or cultural) and their possible equivalence, or the ways in which one may be exchanged for another. Her work is therefore grounded in rich ethnographic material derived from more than 80 interviews conducted in Harbin with sources working in a wide variety of organisations within the Chinese economy: state enterprises and offices, joint Chinese and foreign enterprises, large private enterprises, and small street-level commercial 
firms. Each interviewee was asked to outline his or her previous professional career, to say what they wanted for their children, and to respond to broader questions on their views of society today. ${ }^{3}$ On several occasions Hsu emphasises the importance of her use of monographs. Her investigation was carried out in a city that was affected later than others by the policies of reform and openness, so the personal accounts she reports are firmly rooted in their local context.

3 This book traces the movement from one conception of the social hierarchy to another, i.e., from an order inherited from the state socialism that still predominated in the 1980 s, to a social order based on "quality" (suzhi) that replaced it in the new century. During the first decade of the reforms, the dominant narrative opposed working "within" the state economy to working for the market "on the outside." The social space was structured mainly around this opposition between the state and the market, and people who undertook independent economic activity were considered to have lower status. In the 1990s, mainly in reaction to massive lay-offs in the state sector, such assessments were replaced by a new perspective based on a rhetoric that gave leading importance to the improvement of human capital. The earlier discourse had condemned all entrepreneurs, but the later one divided them into two: on the one hand, the respectable entrepreneurs - qualified, engaged in technological industries, or heading large firms - were viewed as having "quality," while on the other hand, the small individual entrepreneurs - the getihu - were not. This priority given to human capital explains the large investment by families in their children's education.

One of the most interesting aspects of this work is that it shows how a whole range of narratives are simultaneously available at any given moment. With regard to the value accorded to human capital, Hsu refers to the co-existence of narratives in the late 1990s that all tended in the same direction; traditional Confucian legends, state propaganda, or the recruitment practices of firms expressed in job advertisements, all attached value to personal abilities as the principle measure of social success. At other times the available narratives were contradictory. In the 1980s, for example, Hsu points to the competition between the new "meritocratic narrative" on the one hand, produced by governmental policy as it explained that cadres were to be recruited for their abilities and no longer for their political purity, and the "corruption narrative" on the other, produced by dissident voices emphasising prevarication on the part of those in the political apparatuses. These narratives could be of either Chinese or foreign origin. With regard to the social construction of the "entrepreneur" category (Chapter 5), for example, Hsu argues that the widespread availability of biographies of foreign entrepreneurs such as Lee Iacocca (Chrysler) or Bill Gates (Microsoft) contributed towards making Chinese entrepreneurs into heroes.

5 In Hsu's view, ordinary citizens are often the recipients of contradictory narratives from the political elites, local cadres, dissident voices, and Chinese or foreign firms, out of which they make their own discourses. If one follows the evidence that she presents for the plurality of viewpoints, there still remains the problem of how they are appropriated by ordinary citizen. The transformation of the narratives arising from the institutions of power (whether political, media, or scientific) into the personal combinations informing the daily living practices of ordinary citizens, remains largely unclear - in fact, Hsu's analysis proceeds by identifying in the utterances of her informants a number of components that she then attributes to their different sources. 
6 The most convincing part of the book is its comments on the notion of "quality." This concept first emerged in the early 1980s in official propaganda promoting the birth control policy, which was justified by the need to increase the "quality of the population" (renkou suzhi) by reducing its quantity. By the end of the century this idea was put to various uses by society as a whole in such contexts as reforming the educational system, promoting nutritional supplements, and selling apartments ( $\mathrm{p}$. 184). Hsu demonstrates that, contrary to the excessively simplistic views of many analysts, it is not a matter of dominant discourses aimed at oppressing the disadvantaged (such as migrants) in the interests of a neo-liberal ideology. The sources expressed a belief that the main indicator of "quality" was ability (or human capital) and not the level of income (economic capital); even a rich getihu was still a man without quality. This discourse on quality is rooted at one and the same time in a certain traditional Chinese morality, in socialist virtue, and in the requirements of modernity (p. 189).

7 This ambitious work raises a number of questions over its methodology. Although the author distinguishes "public" narratives produced by the authorities from anonymous "collective" narratives shared by all, it is often difficult to grasp the process that produces them. She sometimes moves too quickly from the idea of narrative to that of ideology as a system of values or morality, without allowing the reader to see any clear distinction between them. It would also be helpful to more precisely define what actually constitutes a narrative. In this respect, Hsu relies on rather disparate material, sometimes quoting articles in the press, and other times speeches by leaders or personal testimony. Despite these shortcomings, this work opens up a fruitful path of enquiry for all those seeking a closer understanding of the ways in which Chinese citizens, even within what remains an authoritarian regime, make their own contributions towards shaping the institutions of the socialist market economy.

\section{NOTES}

1. Eric Florence adopts a similar approach, examining both the pronouncements from the dominant apparatuses (the state or the media) about migrant workers, and the narratives produced by the migrants themselves. See Eric Florence, "Migrant Workers in the Pearl River Delta, Discourse and Narratives about Work as Sites of Struggle," Critical Asian Studies, 39:1 (2007), pp. 121-150.

2. This approach is reminiscent of that taken by Luc Boltanski and Laurent Thévenot in Les économies de la grandeur, Paris, PUF, 1987.

3. By putting such questions as: What in your opinion is the main factor for success in contemporary Chinese society? 